\title{
Relationship between Electricity Energy Consumption and GDP: Evidence from India
}

\author{
Asit Mohanty $^{1} \&$ Devtosh Chaturvedi ${ }^{2}$ \\ ${ }^{1}$ Xavier Institute of Management, Xavier University, Bhubaneswar, India \\ ${ }^{2}$ Feedback Energy Distribution Company, Bhubaneswar, India \\ Correspondence: Asit Mohanty, Xavier Institute of Management, Xavier University, Bhubaneswar, India. Tel: \\ 9-178-9441-4730. E-mail: asit.mohanty@ximb.ac.in
}

Received: November 21, 2014

Accepted: December 8, 2014

Online Published: January 25, 2015

doi:10.5539/ijef.v7n2p186

URL: http://dx.doi.org/10.5539/ijef.v7n2p186

\begin{abstract}
The paper examines whether electricity energy consumption drives economic growth or vice versa in the Indian context using the annual data covering the period from 1970-1971 to 2011-2012. KPSS tests reveal that both the series, after logarithmic transformation, are non-stationary at level and stationary at first difference. Applying, two step Engle-Granger technique and Granger causality/ Block exogeneity Wald test, the study suggests that it is the electricity energy consumption that fuels economic growth both in short run and long run. It rejects the neo-classical hypothesis and empirically proves that electricity consumption is a limiting factor on economic growth. Using dynamic OLS(DOLS) method, the elasticity of electricity consumption on economic growth is estimated at 0.86 and the elasticity of economic growth on eletrcity consumption is estimated at 1.19 . Based upon the elasticity, the energy requirement and energy generation is projected at $1436 \mathrm{BU}$ and $1766 \mathrm{BU}$ at the end of 12th Plan (at end of 2016-2017) period.
\end{abstract}

Keywords: energy consumption, economic growth, engle-granger technique and granger causality / block exogeneity wald test, elasticity, India

\section{Introduction}

High levels of economic growth, coupled with growing population and urbanization have resulted in a substantial increase in demand for energy. The relationship between use of energy and economic growth has been a subject of greater interest as energy is considered to be one of the important driving forces of economic growth in all economies (Pokharel, 2006). The dependence on energy by any sector of the economy justifies the link between energy consumption and the overall economic growth rate measured by the Gross Domestic Product in an economy. Therefore, the relationship between energy and economic growth has been a subject of intense research in finding the causal relationship. However, no consensus has arrived from these studies (Soytas \& Sari, 2003). The results from research studies can be categorised into three main categories: (1) no causality, (2) unidirectional causality and (3) bi-directional causality between energy consumption and economic growth. Further, the causal relationship between economic growth and energy consumption is summarized into (a) short term causality (b) long term causality. The relationship between economic growth and energy consumption depends on the structure of the economy. Hence, the findings from the studies differ not only because of the structure of the economy but also across countries, but depend also on methodologies on which the studies have been made (Soytas \& Sari, 2003). The relationship between these two has a major policy implication in framing the energy policy of the concerned country. Convergence on the relationship and magnitude of impact is very much important for policy formulation and implementation.

Keeping in view that electricity is the major source of energy in India and a vital input for infrastructural and socio-economic development, the main objective of this paper is to examine the relationship between electricity energy consumption and GDP in India for the spanning from 1970-1971 to 2011-2012. The present study examines both short term and long term causal relationship. In addition, one of the major objectives of this paper is to estimate the elasticity between electricity energy consumption and Gross Domestic Product (GDP) of India. The study also attempts to forecast the electricity energy consumption and generation based upon the elasticity. Based upon the findings, this study suggests appropriate energy development policies in India specifically relating to electricity sector. 
The remainder of this paper is organized as follows: Section 2 deals with the review of relevant literatures. Section 3 discusses the overview of electricity sector in India. Section 4 describes the data and the methodology followed for the study. Section 5 examines the econometric relationship between electricity consumption and GDP and reports the empirical results. Conclusions and policy implication of the empirical results of the study are presented in section 6 .

\section{Review of Literature}

In most of the studies relating to the relationship between energy and economic growth reveal that co-integration exist and, energy consumption granger causes economic growth not vice versa, therefore, limiting the prospectus for further large reductions in energy intensity (Stern \& Cleveland, 2004).

Akarca and Long (1980), Yu and Hwang (1984), Yu and Choi (1985) and Yu and Jin (1992) observed no relationship between total energy consumption and income for the United States. Whereas, Kraft and Kraft (1978), Stern (1993) and Cheng (1995) have identified a unidirectional causality running from economic growth to energy consumption in USA. Soytas and Sari (2003) investigated the nexus between energy consumption and GDP in France, West Germany, Italy, Japan and Turkey. Their findings support the growth led energy consumption excepting South Korea where the causality runs from energy consumption to GDP. The energy growth nexus is examined by Masih and Masih (1996) in a multivariate framework for economies in Asia such as India; Pakistan; Malaysia; Singapore; Indonesia; Philippines; Korea; and Taiwan. For Malaysia, Singapore and Philippines there neutral nexus is evidenced with consumption led growth for India and Pakistan, and the reverse for Indonesia.

Hence, the empirical research in the energy economic growth nexus can be grouped into Growth-led-Energy, Energy-led-Growth, Growth-led Energy-led-Growth Energy, Energy-led-Growth-led-Energy hypothesis, and the neutrality hypothesis.

The summary of relevant literatures on energy consumption and economic growth nexus is presented in the table give below.

Table 1. Summary of findings from selected literatures

\begin{tabular}{|c|c|c|c|c|c|}
\hline Authors & Year & Country & $\begin{array}{c}\text { Causality from } \\
\text { Growth to energy } \\
\text { consumption } \\
\end{array}$ & $\begin{array}{c}\text { Causality from energy } \\
\text { consumption to } \\
\text { Growth } \\
\end{array}$ & Methodology \\
\hline Kraft and Kraft & 1978 & USA & Yes & & Bivariate Sims causality test \\
\hline Erol and $\mathrm{Yu}$ & 1987 & USA & & Yes & Bivariate Granger test \\
\hline Yu and Jin & 1992 & USA & & Yes & Bivariate Engle \& Granger test \\
\hline Stern & 1993 & USA & Yes & Yes & Multivariate VAR \\
\hline Cheng & 1995 & USA & Yes & Yes & VECM \\
\hline Yu and Choi & 1985 & Philippines & Yes & & \\
\hline Masih and Masih & 1996 & Philippines & No & No & Trivariate VECM \\
\hline Asafu-Adjaye & 2000 & Philippines & Yes & Yes & Trivariate VECM \\
\hline Fatai et al. & 2004 & Philippines & Yes & Yes & Bivariate Toda and Yamamoto \\
\hline Yu and Choi & 1985 & South Korea & & Yes & \\
\hline Masih and Masih & 1996 & India & & Yes & Trivariate VECM \\
\hline Asafu-Adjaye & 2000 & India & & Yes & Trivariate VECM \\
\hline Ghosh & 2002 & India & Yes & & Bivariate VAR \\
\hline Fatai et al. & 2004 & India & & Yes & Bivariate Toda and Yamamoto \\
\hline Paul and Bhattacharya & 2004 & India & Yes & Yes & $\begin{array}{c}\text { Engle-Granger co-integration } \\
\text { Granger Causality }\end{array}$ \\
\hline Glasure and Lee & 1997 & Singapore & Yes & Yes & Bivariate VECM \\
\hline Masih and Masih & 1996 & Singapore & No & No & Trivariate VECM \\
\hline Masih and Masih & 1996 & Malaysia & No & No & Trivariate VECM \\
\hline Cheng and Lai & 1997 & Taiwan & & Yes & \\
\hline Yang & 2000 & Taiwan & Yes & Yes & \\
\hline Asafu-Adjaye & 2000 & Indonesia & & Yes & Trivariate VECM \\
\hline Masih and Masih & 1996 & Indonesia & Yes & & Trivariate VECM \\
\hline Fatai et al. & 2004 & Indonesia & & Yes & Bivariate Toda and Yamamoto \\
\hline
\end{tabular}




\begin{tabular}{|c|c|c|c|c|c|}
\hline Masih and Masih & 1996 & Pakistan & & Yes & Trivariate VECM \\
\hline Soyta and Sari & 2003 & France & Yes & & Bivariate VECM \\
\hline Soyta and Sari & 2003 & West Germany & Yes & & Bivariate VECM \\
\hline Soyta and Sari & 2003 & Italy & Yes & & Bivariate VECM \\
\hline Soyta and Sari & 2003 & Japan & Yes & & Bivariate VECM \\
\hline Soyta and Sari & 2003 & Turkey & Yes & & Bivariate VECM \\
\hline Soytas and Sari & 2003 & South Korea & & Yes & Bivariate VECM \\
\hline Yu and Choi & 1985 & South Korea & Yes & & Bivariate Granger test \\
\hline Glasure and Lee & 1997 & South Korea & Yes & Yes & Bivariate VECM \\
\hline Oh and Lee & 2004 & South Korea & Yes & Yes & Trivariate VECM \\
\hline Asafu-Adjaye & 2000 & Thailand & Yes & Yes & Trivariate VECM \\
\hline Masih and Masih & 1998 & Thailand & Yes & & Trivariate VECM \\
\hline Masih and Masih & 1998 & Sri Lanka & & Yes & Trivariate VECM \\
\hline Morimoto and Hope & 2004 & Sri Lanka & & Yes & Standard Granger causality \\
\hline Asafu-Adjaye & 2000 & Thailand & Yes & Yes & Trivariate VECM \\
\hline Fatai et al. & 2004 & Thailand & Yes & Yes & Bivariate Toda and Yamamoto \\
\hline Hondroyiannis et al. & 2002 & Greece & Yes & Yes & Trivariate VECM \\
\hline Wolde-Rufael & 2004 & Shanghai & & Yes & Bivariate Toda and Yamamoto \\
\hline Hou & 2009 & China & Yes & Yes & Hsiao’s Granger causality \\
\hline Lee & 2005 & $\begin{array}{c}18 \text { developing } \\
\text { countries }\end{array}$ & & Yes & Trivariate Panel VECM \\
\hline Al-Iriani & 2006 & Gulf Countries & Yes & & Bivariate Panel VECM \\
\hline Borozan & 2013 & Croatia & & Yes & Bivariate VAR \\
\hline Adom & 2011 & Ghana & & Yes & Bivariate Toda and Yamamoto \\
\hline Akinlo & 2008 & Ghana & & Yes & Full Modified OLS \\
\hline
\end{tabular}

It is emerged from the survey of literatures that there is no consensus on the relationship between energy consumption and economic growth mainly because of country specific economic structures, methodology adopted and varying period of study. Country wise findings are presented. Since, the focus of the study is on India, broadly, there is a consensus on Energy-GDP nexus, wherein, energy led growth hypothesis is established.

Besides, the energy-growth nexus, estimation of elasticity of energy consumption on GDP and elasticity of GDP on energy consumption is also vital for policy formulation and implementation. Campo and Sarmiento (2011) in their analysis spanning from 1971 to 2007 on ten Latin American countries have identified the long run relationship between energy consumption and GDP. After establishing the long run relationship, they have estimated the long run elasticity of energy consumption on GDP as well as elasticity of GDP on electricity consumption for all the ten countries. The following table gives the estimated elasticity.

Table 2. Estimated elasticity for Latin American economies

\begin{tabular}{lcc}
\hline Countries & $\boldsymbol{\beta}_{\mathbf{1}}$ & $\boldsymbol{\beta 2}$ \\
\hline Argentina & 1.433 & 0.533 \\
Bolivia & 0.214 & 0.18 \\
Brazil & 1.236 & 0.189 \\
Chile & 1.141 & 0.40 \\
Colombia & 0.154 & 0.815 \\
Ecuador & 0.204 & 0.739 \\
Paraguay & 0.115 & 0.693 \\
Perú & 0.379 & 0.786 \\
Uruguay & 0.367 & 0.783 \\
Venezuela & 0.655 & 0.82 \\
\hline
\end{tabular}

Note. $\beta_{1}$ : Elasticity of Energy consumption on GDP; $\beta 2$ : Elasticity of GDP on Energy consumption.

Source: Campo and Sarmiento (2011).

$\boldsymbol{\beta}_{1}$ is highest for Argentina at 1.43 which implies that $10 \%$ rise in energy consumption would lead to $14.3 \%$ rise 
in real GDP. $\boldsymbol{\beta}_{2}$ is highest for Colombia and Venezuela at 1.43 which implies that $10 \%$ rise in real GDP would lead to $8.2 \%$ rise in energy consumption.

It is important to estimate the elasticity of energy consumption on GDP when it is Energy led GDP. If it is GDP led Energy, it is vital to estimate the elasticity of GDP on energy consumption. This estimation helps in projecting the energy consumption and GDP.

The Planning Commission, Govt. of India (2014) has estimated the elasticity of electricity consumption with respect to GDP from first plan to eleventh plan. The elasticity relating to different plan period is tabulated below.

Table 3. Elasticity of electricity consumption w.r.t. GDP

\begin{tabular}{ccc}
\hline Plan & Period & Elasticity \\
\hline First & $1951-1956$ & 3.14 \\
Second & $1956-1961$ & 3.38 \\
Third & $1961-1966$ & 5.04 \\
Fourth & $1969-1974$ & 1.85 \\
Fifth & $1974-1979$ & 1.88 \\
Sixth & $1980-1985$ & 1.39 \\
Seventh & $1985-1990$ & 1.5 \\
Eighth & $1992-1997$ & 0.97 \\
Ninth & $1997-2002$ & 0.64 \\
Tenth & $2002-2007$ & 0.9 \\
Eleventh & $2007-2012$ & 1.04 \\
\hline
\end{tabular}

Source: The Planning Commission, Govt. of India (2014).

As shown in the table, the elasticity of electricity consumption on GDP has been declining since the third plan period. The average elasticity from 1969-2012 (Fourth Plan to Eleventh Plan Period) is calculated at 1.27. The Ministry of Power, Govt. of India (2012) has forecasted elasticity of 0.9 for 12th Plan (2012-2017) and 0.8 for 13th Plan (2017-2022). Based upon this elasticity, the projection of energy requirement is pegged at $1403 \mathrm{BU}$ (billion unit) at the end of 2016-2017 (end of 12th Plan) and 1993 BU at the end of 2021-2022 (end of 13th Plan).

\section{Overview of Electricity Sector in India}

Energy is needed for economic growth, for improving the quality of life and for increasing opportunities for development. Some 600 million Indians do not have access to electricity and about 700 million Indians use biomass as their primary energy resource for cooking. Ensuring life line supply of clean energy to all is essential for nurturing inclusive growth, meeting the millennium development goals and raising India's human development index that compares poorly with several countries that are currently below India's level of development (Note 1).

The different sources of energy are Petroleum, Coal, Hydroelectricity, Natural Gas Nuclear and Renewable Energy. India has the fifth largest generation capacity in the world with an installed capacity of which is about 4 percent of global power generation. The top four countries, viz., US, Japan, China and Russia together consume about 49 percent of the total power generated globally. The installed generation capacity in India has stood at 2,50,256 MW at the end of 30th July 2014 (Note 2). The value chain of electricity sector is entirely dominated by central, state and private sector utilities. The contribution the State Sector, Central Sector and Private Sector are $39.37 \%, 28.73 \%$ and $31.88 \%$ respectively to the total installed capacity in India (Note 3 ). The following Figure shows the share of sources of energy in total installed capacity at the end of 2013-2014. The thermal and hydroelectricity constitutes $66 \%$ of the installed capacity. 


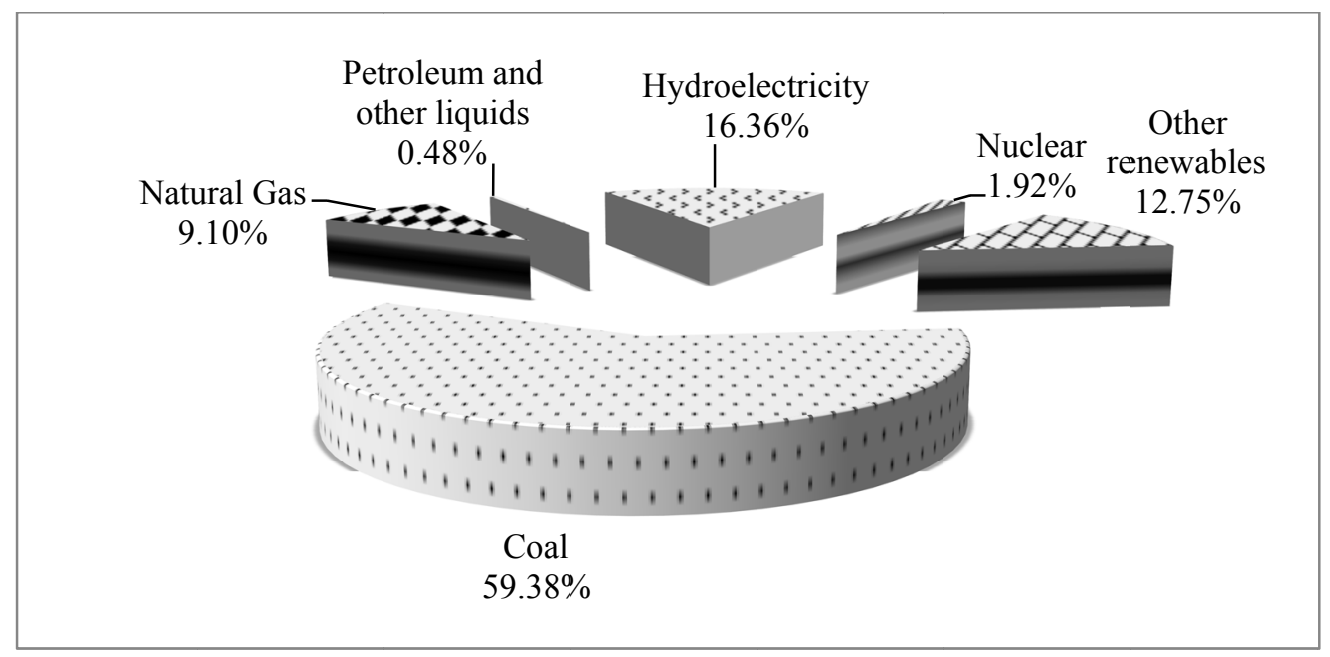

Figure 1. Utility based installed power capacity

Source: Central Electrical Authority, India.

The mixed energy basket of India is dominated by coal which would continue in future. Electricity being the primary energy is produced from coal, hydro, nuclear and other renewable sources.

Rapid growth of the Indian economy places a heavy demand on electric power. India is the fourth-largest energy consumer in the world after China, the United States, and Russia, and its need for energy supply continues to climb as a result of the country's dynamic economic growth and modernization over the past several years (Note 4). The major source of energy consumed was Electricity accounting for about $51 \%$ of the total consumption during 2010-2011. Coal and Lignite were second (25\%), while Crude Petroleum (20\%) was third (Note 5).

The total generation (Note 6 ) of the electricity has grown at a rate of $6.96 \%$ on annual compound average growth rate (CAGR) basis (Note 7) from 1970-1971 to 2011-2012. During the same period, the consumption of electricity grew at a rate of $6.62 \%$ on annual CAGR basis which is relative lower than the CAGR of electricity generation. Since, electricity consumption is derived from netting the Transmission \& Distribution (T\&D) losses from total generation, it is implied that the growth in T\&D losses is reason for relatively lesser growth in consumption. In fact, T\&D losses witnessed a CAGR of $8.1 \%$ during the same time period. However, the CAGR of GDP at current prices (nominal GDP) has recorded 12.9\%, outpacing the growth rate in both generation and consumption of electricity.

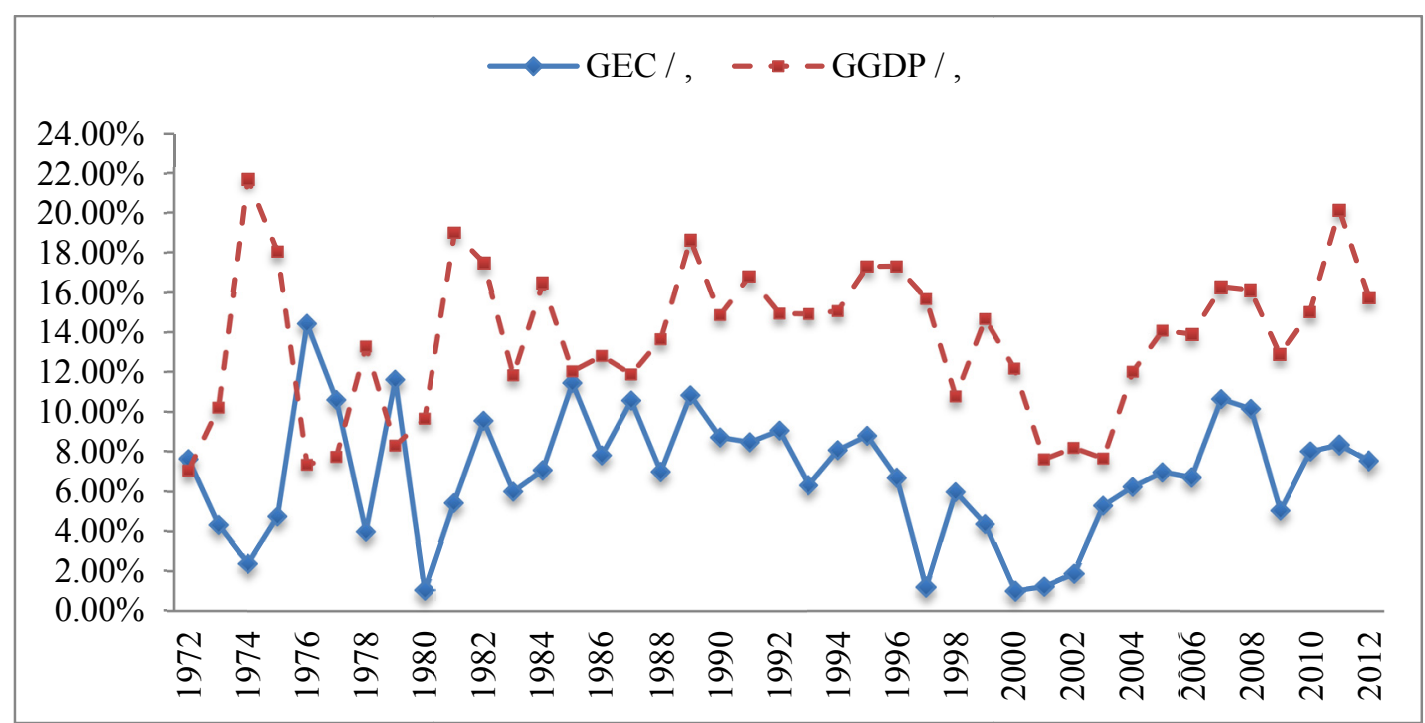

Figure 2. Year to year growth in electricity consumption and nominal GP

Source: CMIE, *GEC \& GGDP is annual growth rate in electricity consumption and nominal GDP. 
Table 4. Descriptive statistics

\begin{tabular}{lllll}
\hline & GEC & GGDP & GEG & GTD \\
\hline Mean & $6.91 \%$ & $13.70 \%$ & $6.92 \%$ & $7.87 \%$ \\
Std. Dev. & $3.22 \%$ & $3.78 \%$ & $2.97 \%$ & $6.08 \%$ \\
Skewness & $-13.12 \%$ & $-14.16 \%$ & $0.07 \%$ & $66.87 \%$ \\
Kurtosis & $276.69 \%$ & $236.45 \%$ & $270.95 \%$ & $353.47 \%$ \\
Median & $6.99 \%$ & $14.10 \%$ & $6.93 \%$ & $7.12 \%$ \\
Minimum & $0.98 \%$ & $7.06 \%$ & $0.25 \%$ & $-1.94 \%$ \\
Maximum & $14.44 \%$ & $21.71 \%$ & $12.99 \%$ & $25.73 \%$ \\
\hline
\end{tabular}

Source: CMIE

As shown in Figure 2, the co-movement between growth rate in electricity consumption and GDP exists from 1980-1981 onwards. The descriptive statistics of annual growth rate in electricity Consumption (GEC), GDP (GDP), electricity generation (GEG) and T\&D losses (GTD) is presented below.

Some observations are emerging from the table 4. The minimum and maximum of GEC is more than GEG which implies the energy deficit. In fact, energy deficit has been witnessed in India since 1980-1981. The energy deficit relative to energy requirement is recorded at 8\% annually from 1980-1981 to 2011-2012. In 1980-1981, the energy deficit was at $16,384 \mathrm{MU}$ and increased by at $5.8 \%$ on annual CAGR basis to reach at a deficit level of $86905 \mathrm{MU}$ at the end of 2011-2012. High levels of economic growth, coupled with growing population and urbanization have resulted in a substantial increase in demand for power. However, power supply has been lagging behind; in 2011-2012, the country had a power deficit of nearly 8.7\% per cent of the total requirement.

GEC has negatively skewed as compared to GEG which is positively skewed. This has resulted into positive skewness of GTD. The average T\&D losses relative to total generation are at $24.1 \%$ which is quite high as compared to international benchmark of $8-9 \%$ (Note 8 ). High variation is observed in case of GTD.

Both at national and international level, Per-capita Energy Consumption (PEC) PEC and Energy intensity (EI) are the most used policy indicators, both at national and international levels. High energy efficiency indicated by low EI usually refers to less use of energy per unit of output. Gain in energy efficiency directly increases energy uses by other economic activities which further stimulates economic growth. Gain in energy efficiency means may lead reduction in price of certain consumer products which in turn, spurs an increase in the demand for energy indirectly through released purchasing power redirected to energy-using goods and services.

PEC is the total energy consumption during the year relative to the estimated mid-year population of that year. Energy Intensity is defined as energy consumed for producing one unit of Gross Domestic Product (At constant prices). In the absence of data on consumption of non-conventional energy from various sources, particularly in rural areas in the developing countries, including India, these two indicators are generally computed on the basis of consumption of conventional energy (Note 9). The PEC has increased from 1204 unit (KWH) in 1970-1971 to 4816 unit in 2010-2011, a CAGR of 3.44\%. The annual increase in PEC from 2009-2010 to 2010-2011 was $3.65 \%$. The PEC of India is one-third of the international average (Note 10) indicating potentially higher energy demand in the long term as the country continues its path of economic development.

The Energy Intensity which indicates the energy efficiency (at 1999-2000 prices) increased from 0.128 KWh in 1970-1971 to $0.165 \mathrm{KWh}$ in $1985-1986$, but it has come down to $0.117 \mathrm{KWh}$ (at 2004-2005 prices) in 20102011. If the growth in electricity consumption relative to growth in GDP in each year is taken as proxy for electricity intensity, then the average electricity intensity is estimated at 0.55 during the period 1971-1972 to 2011-2012. The trend is given below in the Figure 3: 


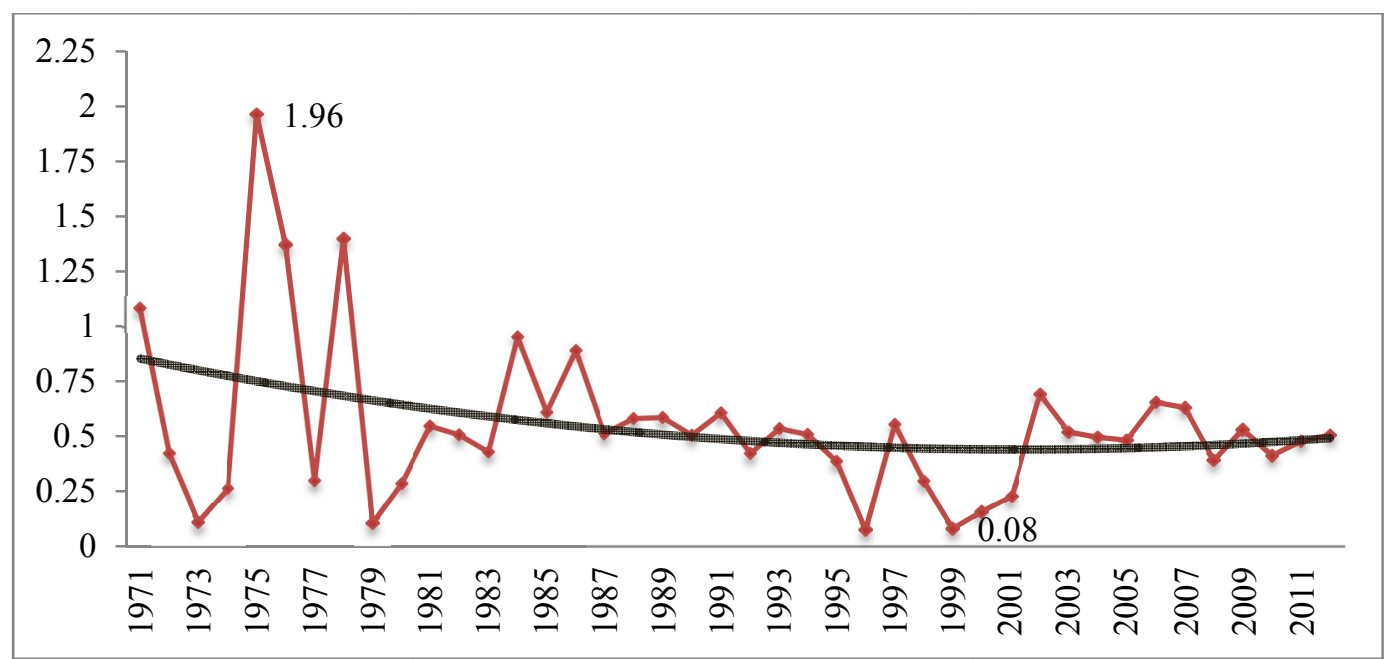

Figure 3. Electricity intensity (1971-1972 to 2011-2012)

Source: CMIE.

Though, the intensity has declined over the period, the rate of decline has not been significant. The annual decline has been $0.9 \%$ since 1971-1971. Huge fluctuations have been observed over the period which is represented by a high standard deviation of $37 \%$. Hence, the decline in the electricity intensity has been very slow and not consistent.

The average primary energy intensity of India is 0.20 (koe/ $\$ 05 p)$ during $2005-2011$ as against the Global average of $0.19(\mathrm{koe} / \$ 05 \mathrm{p})$ (Note 11). The comparison of EI (koe $/ \$ 05 \mathrm{p})$ of India with some selected countries is presented below.

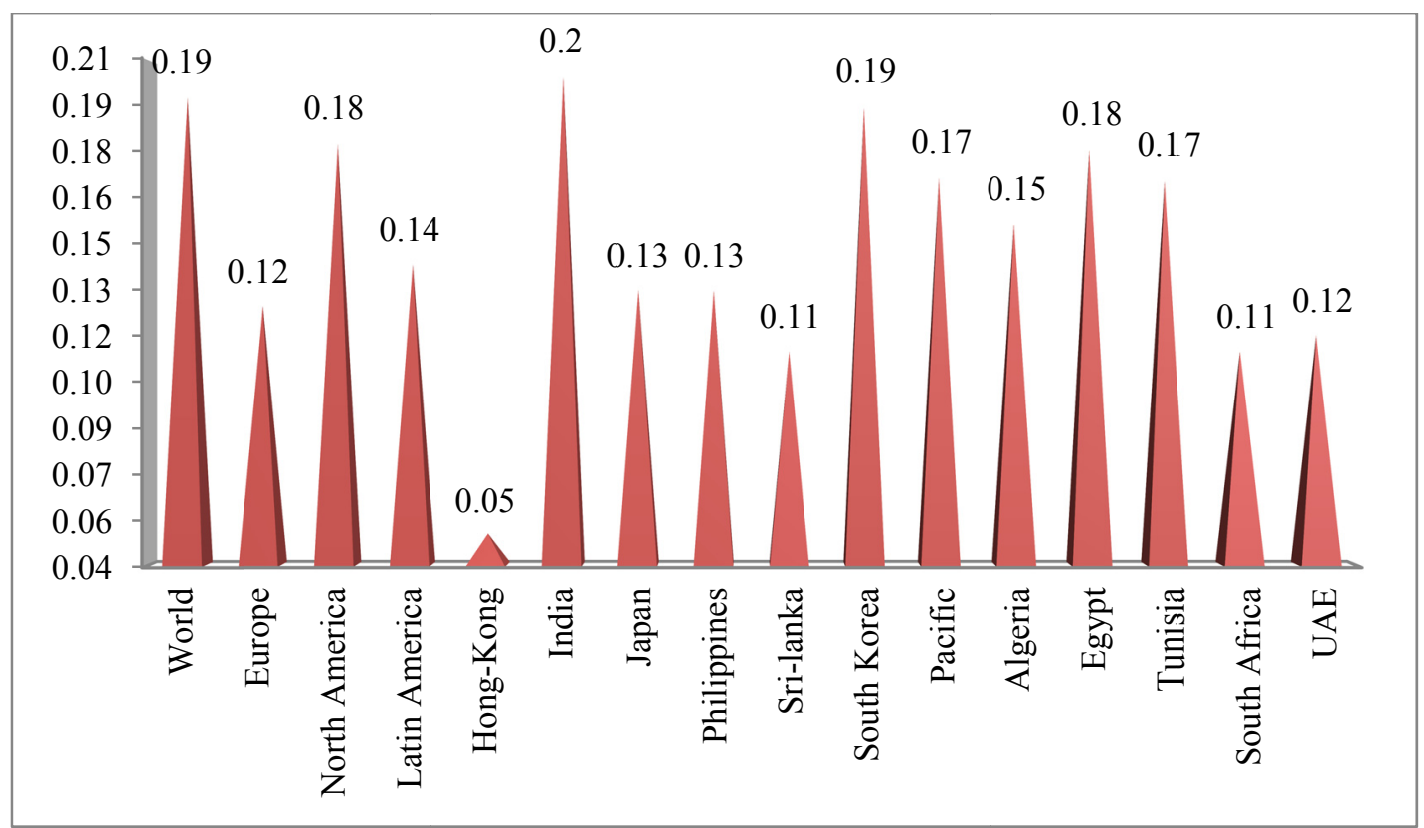

Figure 4. Country wise comparison of energy intensity (koe/\$05p)

Source: World Energy Council.

The EI of India is higher than global average and much higher than Europe, Latin America, and Pacific Countries. It is also more as compared to some Asian and African countries. The high energy intensity level in India coupled with high T\&D loss is a limiting factor for gain in efficiency, thereby, constraining the potential for further increase in economic activities and economic growth. 
Buoyancy of GDP relative to electricity consumption implies the percentage change in GDP for one percentage change in electricity consumption. The trend line is Figure 3 presented below.

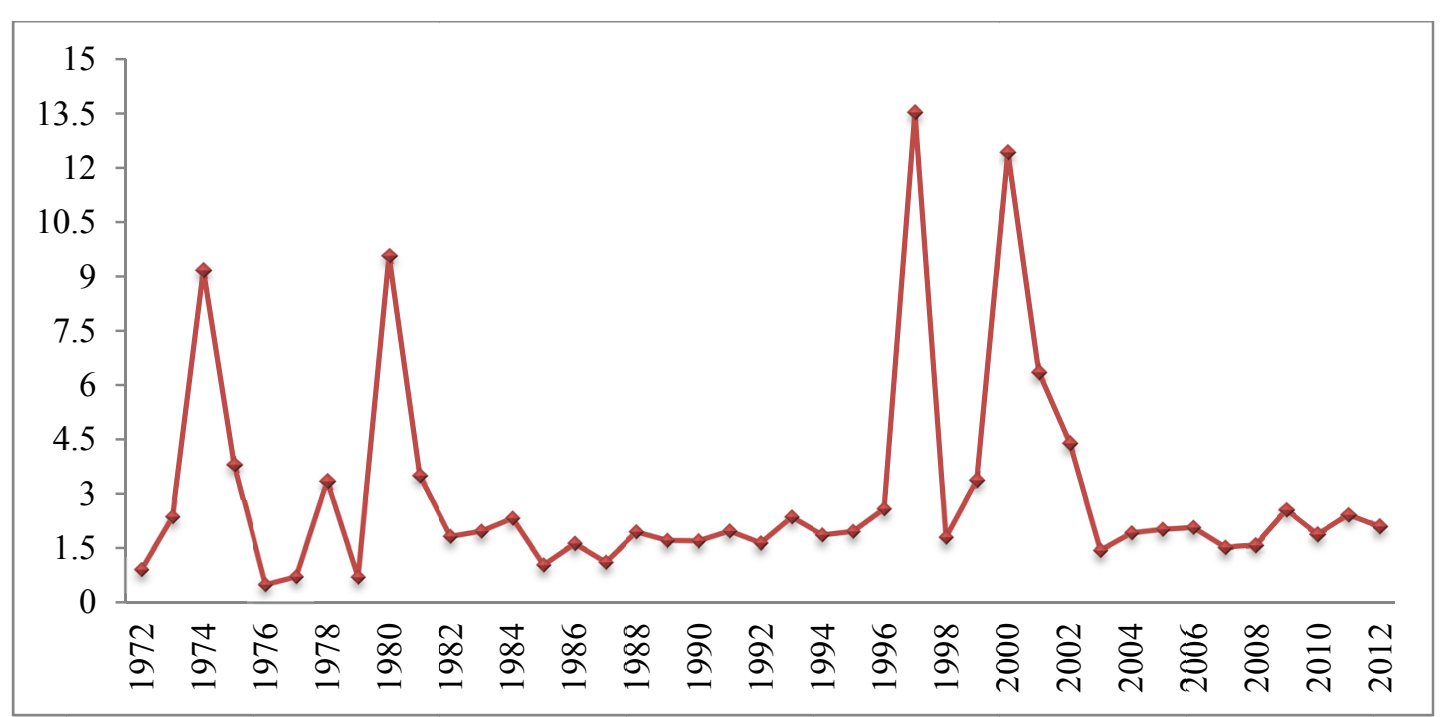

Figure 5. Trend in buoyancy of GDP relative to electricity consumption

Source: CMIE.

The mean buoyancy of GDP relative to electricity consumption during the period of the study is calculated at 3.021 , implying that one percentage change in electricity consumption leads to three times increase in nominal GDP growth. However, over the period, the fluctuation in buoyancy has been very high represented by high standard deviation of 2.97. The maximum and minimum value of buoyancy has been calculated as 13.54 and 0.509 respectively. The high mean buoyancy at 3 indicates high sensitiveness of growth in GDP relative to growth in electricity consumption. Indirectly, nexus between electricity consumption and GDP is established from the buoyancy analysis.

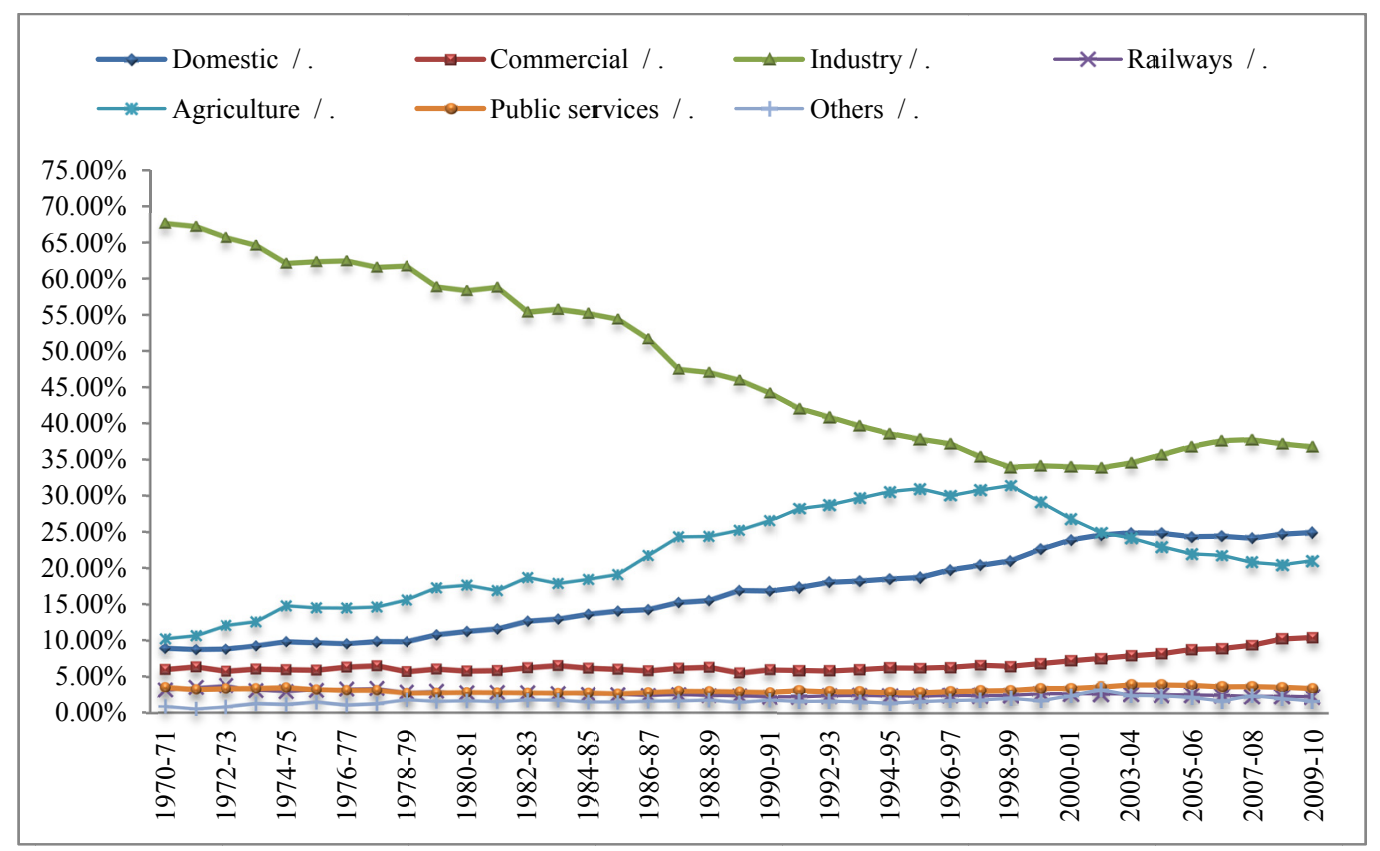

Figure 6. Consumer wise share (\%) in electricity sales

Source: CMIE. 
The consumer wise share in electricity sales (in percentage) by the distribution utilities in India from 1970-1971 to 2009-2010 is given in the Figure 4.

The largest consumer of electricity in India is the industrial sector, with an average share of $48 \%$ per cent, followed by the agricultural and domestic sectors with shares of $21.54 \%$ and $16.52 \%$ respectively during 1970 1971 to 2009-2010. Commercial, Public services and Railways constitute 6.63\%, 3.08\% and 1.61\% respectively during the same period. This pattern is in commensurate with the contribution of the respective sectors to the GDP. Industry and Services sectors contribute $86 \%$ to the GDP and agricultural sector share is at $14 \%$ (Note 12 ). This indirectly dives idea about energy and growth nexus. The CAGR of electricity consumer wise electricity sales during this period is given in Figure 5.

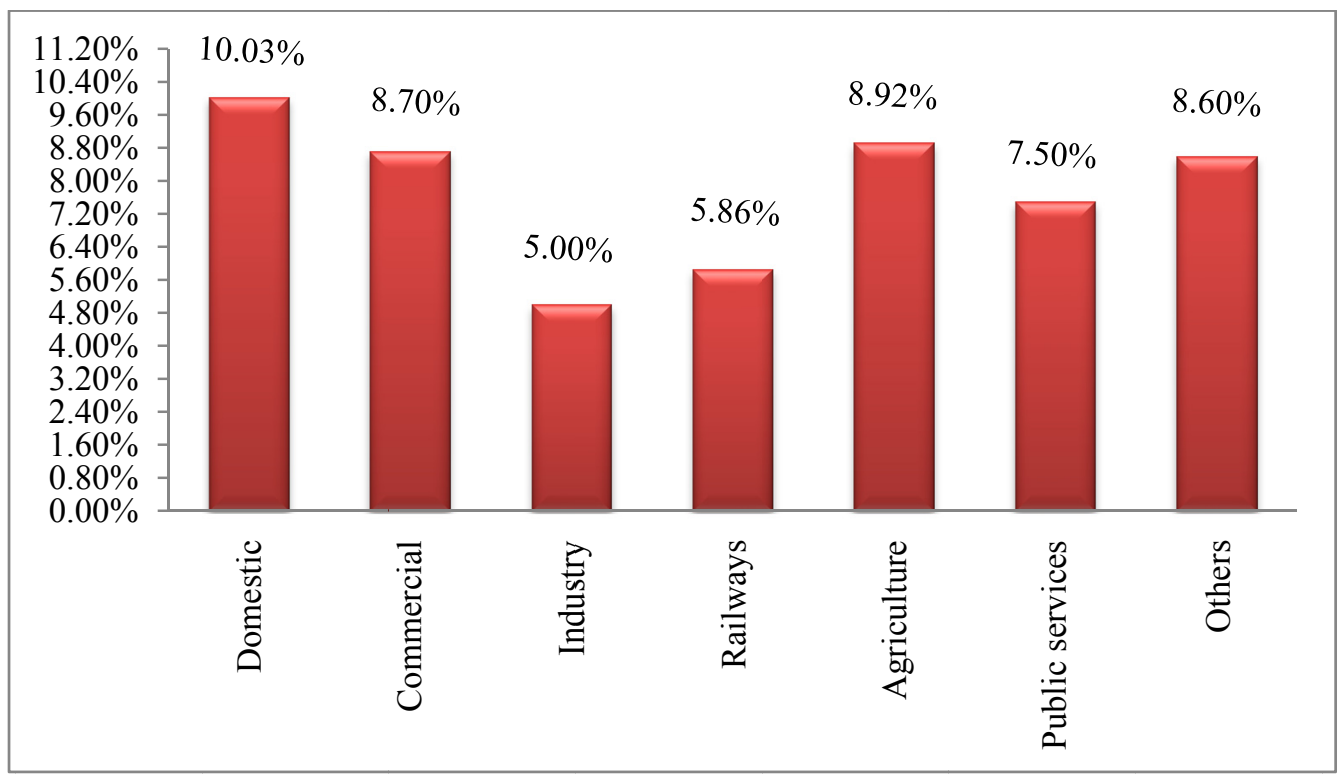

Figure 7. CAGR of electricity sales from 1970-1971 to 2009-2010

Source: CMIE

The sector with the fastest growth in consumption in the last forty years has been the domestic (household) sector; consumption of electricity has increased sixteen times over the 1980 levels, corresponding to CAGR of 10 per cent. This increase is primarily due to the inclusion of households in areas that had no access to power previously. The share of the agricultural sector in power consumption increased eleven-fold, registering CAGR of 8.92 per cent. Again, the principal reason behind the strong growth has been the increased energy access in rural areas.

\section{Data and Methodology}

The relevant data is collected for the period from 1970-1971 to 2011-2012. The table given below presents the details of these data sources.

Table 5. Data sources

\begin{tabular}{lllll}
\hline Data & Period & Basis & Source \\
\hline $\begin{array}{l}\text { Data Relating to Electricity Sector in } \\
\text { India }\end{array}$ & $1970-1971$ to 2011-2012 & Annual & Centre for & Monitoring \\
$\begin{array}{l}\text { Data relating to Real GDP (at 2004- } \\
\text { 2005 Prices) and Nominal GDP (at }\end{array}$ & & Annual & $\begin{array}{l}\text { Reserve Bank of India, Ministry of Statistics } \\
\text { and Program Implementation }\end{array}$ \\
Current Prices ) & & & \\
\hline
\end{tabular}

The Engle and Granger (EG, 1987) two step modeling method is applied to detect the relationship between electricity consumption and GDP. In first step, stationarity and cointegration of the time series data on electricity consumption and GDP at current prices have been examined using Kwiatkowski-Phillips-Schmidt-Shin (KPSS) 
unit root tests. As a part of second step of EG procedures, Error Correction Mechanism (ECM) is applied to test the long run equilibrium relationship. Granger causality/ Block exogeneity Wald test is applied to investigate the short run causality. Dynamic OLS method is used to estimate the elasticity.

\section{Empirical Results}

\subsection{Testing for Stationary Nature of Data}

To examine the relationship between electricity consumption and GDP of India, it is first established whether these time series data are stationary or not. This is done by performing a unit root test on time series data wherein, the unit root test identifies variables that are non-stationary, meaning that they contain stochastic trend that leads them to wander randomly. The presence of unit root is examined using the Kwiatkowski-PhillipsSchmidt-Shin (KPSS) unit root tests (KPSS 1992).To test whether a series, y(t), has a unit root or not, the following model is taken into account.

$$
\left.\Delta y(t)=\alpha+\beta t+(\rho-1) y(t-1)+\Sigma_{(j=1} \text { to } n\right) \rho(j) \Delta y(t-j)+\varepsilon(t)
$$

Both drift and time trend are captured in modeling the series, as time series are observed to have both these components. The $\mathrm{n}$ lag terms have been taken to protect against the possibility that $\mathrm{y}(\mathrm{t})$ follows a higher order autoregressive process.

The null hypothesis for the KPSS test is that the data series is stationary and, hence, the time series $y(t)$ does not have unit root. This is tested against the alternate hypothesis that that unit root exists and the series $y(t)$ is nonstationary. KPSS test is considered as more powerful tool to test the unit root when there are multiple break points in time series data (Note 13). Since, electricity consumption and GDP time series data have multiple break points( Annex -1), KPSS test is adopted. The test statistic is called LM statistic which based upon asymptotic distribution If the LM stat is less than the asymptotic critical values tabulated by KPSS, then null hypothesis of stationary nature of data is accepted.

The natural logarithmic value of electricity consumption and real GDP is taken to check the unit root. The result of unit root test is given in table 6 .

Table 6. Testing presence of unit roots using KPSS test

\begin{tabular}{cccc}
\hline Time Series Data & Data Points & LM stat & Asymptotic Critical value at $1 \%$ \\
\hline LEC & 42 & 0.80 & 0.74 \\
LGDP & 42 & 0.81 & 0.73 \\
$\Delta$ LEC & 41 & 0.08 & 0.21 \\
$\Delta$ LGDP & 41 & 0.08 & 0.21 \\
\hline
\end{tabular}

Note. *LEC and LGDP are logarithmic value of Electricity Consumption and GDP respectively.

Hence, both electricity consumption and GDP are non-stationary at level. They are stationary at first difference level at $1 \%$ level or difference stationary.

\subsection{Co-integration Test}

After establishing the non-stationary nature of LCE and LGDP at level and stationary nature at first difference, the existence of any long-term equilibrium relationship between these two time series variables is examined. For examining this, the concept of co-integration is applied. Co-integration implies an equilibrium relationship which is a pre-requisite for testing and estimating long run (equilibrium) relationship among selected variables. The co-integration methodology is the two-step process suggested by Engle and Granger (1987).

Two series, $\mathrm{z}(\mathrm{t}) \sim \mathrm{I}(1)$ and $\mathrm{x}(\mathrm{t}) \sim \mathrm{I}(1)$ are said to be co-integrated if there exists a $\beta$ such that $\mathrm{z}(\mathrm{t})-\beta \mathrm{x}(\mathrm{t})$ is $\mathrm{I}(0)$ (Maddala 2001). This leads to the following regression equation:

$$
z(t)=\beta x(t)+u(t)
$$

Where, $\mathrm{u}(\mathrm{t})$ is $\mathrm{I}(0)$ variable, $\mathrm{z}(\mathrm{t})$ and $\mathrm{x}(\mathrm{t})$ do not drift too far apart from each other over time. If $\mathrm{z}(\mathrm{t})$ and $\mathrm{x}(\mathrm{t})$ are not co-integrated, then $\mathrm{u}(\mathrm{t})$ will be $\mathrm{I}(1)$, which means that $\mathrm{x}(\mathrm{t})$ and $\mathrm{y}(\mathrm{t})$ can drift apart more and more over time. In this case, the relationship obtained by regression $z(t)$ over $x(t)$ is not valid and is of the nature of "spurious regression".

Here, $z(t)$ is the logarithm value of electricity consumption and $x(t)$ the is the logarithm value of GDP. The co-integration regression is carried out on these two variables by the ordinary least squares (OLS) method. 


$$
z^{\prime}(t)=\alpha+\beta x(t)
$$

Where $z^{\prime}(t)$ is the estimated $z(t)$.

Next, the co-integrating residual, $\mathrm{u}(\mathrm{t})$ is derived as:

$$
u(t)=z(t)-z^{\prime}(t)
$$

Unit root test is applied on these residuals $u(t)$ for unit root test using the KPSS test. A slight modification is made to the normal test (equation 1) as it is based on calculated least square residuals. The model used is:

$$
\Delta u(t)=(\rho-1) u(t-1)+\Sigma_{(j=1 \text { to } n)} \rho(j) \Delta u(t-j)+\varepsilon(t)
$$

As compared to (1), the drift and the trend part have been removed in (5). In KPSS test,the null hypothesis $\mathrm{H}_{0}$ is implies that $\mathrm{u}(\mathrm{t})$ are stationary. Hence, there is long run relationship between $\mathrm{x}(\mathrm{t})$ and $\mathrm{z}(\mathrm{t})$, hence they are co-integrated. The alternate hypothesis $\mathrm{H}_{1}$ is $\mathrm{x}(\mathrm{t})$ and $\mathrm{z}(\mathrm{t})$ are not co-integrated. Using LM statistic, the residuals from above regression are examined for $\mathrm{I}(0)$ or stationary. The results are given in table 7 .

Table 7. Results of KPSS test for cointegration

\begin{tabular}{llccl}
\hline Co-integration Test with LGDP & $\begin{array}{c}\text { Number of } \\
\text { Data Points }\end{array}$ & LM stat & $\begin{array}{c}\text { Asymptotic critical } \\
\text { values at 1\% }\end{array}$ & Conclusion \\
\hline LEC & 42 & 0.2112 & 0.7390 & H0 is accepted, Co-integration exists. \\
LGDP & 42 & 0.2150 & 0.7390 & H0 is accepted, Co-integration exists. \\
\hline
\end{tabular}

From the results given in table 7 , it can be inferred that the electricity consumption and GDP are non-stationary at level. However, the co-integration between these two non-stationary series is established implying that that both the have a tendency to converge systematically in the long-run, even if they may drift apart in the short-run.

\subsection{Error Correction Mechanism}

After establishing co-integration and long run equilibrium relationship, the short run equilibrium relationship is examined by using the Granger representation theorem (Gujarati, 1995). The short-term relationship between the two variables is presented in the form of an Error Correction Model (ECM).

$$
\begin{gathered}
\triangle L G D P=\alpha_{0}+\alpha_{1} \Delta L E C+\alpha_{2} u_{t-1}+\varepsilon_{t} \\
\triangle L E C=\beta_{0}+\beta_{1} \Delta L G D P+\beta_{2} u_{t-1}^{\prime}+\varepsilon_{t}^{\prime}
\end{gathered}
$$

In equation (6), $\Delta$ denotes the first difference operator, $\varepsilon_{\mathrm{t}}$ is a random error term, and $\mathrm{u}_{\mathrm{t}-1}=\mathrm{LGDP}_{\mathrm{t}-1}-\delta_{1}-$ $\delta_{2} \mathrm{LEC}_{\mathrm{t}-1}$, that is, the one period lagged value of error from the co -integrating regression Similarly in equation (7) $\Delta$ denotes the first difference operator, $\varepsilon_{\mathrm{t}}$ is a random error term, and $\mathrm{u}_{\mathrm{t}-1}=\mathrm{LEC}_{\mathrm{t}-1}-\delta_{{ }_{1}}-\delta_{{ }_{2}} \mathrm{LGDP}_{\mathrm{t}-1}$, that is, the one period lagged value of error from the co integrating regression.

According to the Granger representation theorem(GRT), negative and statistically significant $\boldsymbol{\alpha}_{2}$ and $\boldsymbol{\beta}_{\mathbf{2}}$ is a necessary condition for the variables in hand to be co-integrated. In practice, this is regarded as an convincing evidence and confirmation for the existence of cointegration found in the first step. It is also important to note that, in the second step of the EGM, there is no danger of estimating a spurious regression because of the nature stationary of the variables ensured. Combinations of these two steps then provide a model incorporating both the static long-run and the dynamic short-run components.

The short run dynamics of the equation (6) \& (7) are examined through multiple regressions on model given in (8 \& 9). The results are given below:

$$
\begin{aligned}
& \triangle L G D P=0.1228+0.0 .724 * \Delta L E C P-0.0795 * u_{t-1}+\varepsilon_{t} \\
& \triangle L E C=0.0573+0.0704 * \Delta G D P-0.0484 * u^{\prime}{ }_{t-1}+\varepsilon^{\prime}{ }_{t}
\end{aligned}
$$

In equation (8), the negative value of $\boldsymbol{\delta}_{\mathbf{2}}$ shows that $7.95 \%$ of the discrepancy between the two variables is eliminated in the next year. The 't ratio' of $\boldsymbol{\delta}_{\mathbf{2}}$ is also significant at -2.158 ( $\mathrm{p}$ value 0.0373 ) indicating that the impact of electricity consumption on GDP is stable in the long run. As equation (9) shows, the negative value of $\boldsymbol{\delta}_{2}{ }_{2}$ shows that $4.8 \%$ of the discrepancy between the two variables is eliminated in the next year. However, the' $\mathbf{t}$ ratio' is very low at -0.6754 ( $p$ value 0.5035 ) and, not insignificant, indicating that the impact of GDP on electricity consumption is not stable in the long run. From the above results, it is empirically established that electricity consumption has a stable long run impact on the GDP. In other words, the long run equilibrium causal 
relationship runs from electricity consumption to GDP and not vice versa.

\subsection{Short Term Causality}

After establishing, the long run association between electricity consumption, the short run association is examined by applying Granger causality/ Block exogeneity Wald test (Enders, 2003, p. 284). Granger causality indicates that lagged values of a variable provide statistically significant information to predict another variable. Essentially, Granger causality tests the presence of correlation between the current value of one variable and the lagged values of other variables in the system. In addition, Granger causality tests decide about the exogeneity of a variable. This test detects whether the lags of block variables can Granger-cause any other variables in the VAR system. For example, rejection of the null hypothesis implies that if all lags of electricity consumption cannot be excluded in explaining GDP, then GDP is an endogenous variable and there is causality of electricity consumption on GDP. Therefore, in order to determine which variables are exogenous in the VAR model, the Granger causality/block exogeneity Wald tests are undertaken. The lag order of 1 is selected based upon schwarz information criterion (SIC). The output of the test is given below.

Table 8. VAR granger causality/block exogeneity wald tests

\begin{tabular}{|c|c|c|c|}
\hline \multicolumn{4}{|c|}{ Sample: 19712012} \\
\hline \multicolumn{4}{|c|}{ Included observations: 41} \\
\hline \multicolumn{4}{|c|}{ Dependent variable: LEC } \\
\hline Excluded & Chi-sq & Df & Prob. \\
\hline LGDP & 0.230859 & 1 & 0.6309 \\
\hline All & 0.230859 & 1 & 0.6309 \\
\hline \multicolumn{4}{|c|}{ Dependent variable: LGDP } \\
\hline Excluded & Chi-sq & Df & Prob. \\
\hline LEC & 4.908721 & 1 & 0.0267 \\
\hline All & 4.908721 & 1 & 0.0267 \\
\hline
\end{tabular}

The null hypothesis of GDP does not cause electricity consumption is accepted at $95 \%$ level of significance with low chi square value. The null hypothesis of electricity consumption does not cause GDP is rejected at 95\% level of significance and high chi square value. The results show that in the short run, causality runs from electricity consumption to GDP but not vice versa. This corroborates the findings of the equation (8).

\subsection{Estimation of Long Run Elasticity}

The elasticity can be estimated by transforming both the variables into logarithmic form (double log model).

$$
\begin{aligned}
& L G D P=a_{0}+a_{1} L E C+u_{t} \\
& L E C=b_{0}+b_{l} L G D P+v_{t}
\end{aligned}
$$

Where:

' $a$ ' is the degree of responsiveness of real GDP for one percentage change in electricity consumption.

' $b_{1}$ ' is the degree of responsiveness of electricity consumption for one percentage change in real GDP.

The DOLS technique is applied for calculating the long-run elasticity. The Dynamic OLS procedure introduced by Stock and Watson (1993) involves estimation of long-run equilibrium via dynamic OLS (DOLS). DOLS involves in regressing one of the $\mathrm{I}(1)$ variables on other $\mathrm{I}(1)$ variable by augmenting the co-integrating equation with lags and lead of these first difference of the regressor. The essence of incorporating the first difference variables and the associated lags and leads is to make the resulting co-integrating equation error term is orthogonal and to correct for regressor endogeneity. In addition it has the same asymptotic optimality properties as the Johansen distribution. HAC (Newey-West) covariance matrix estimator is adopted in executing DOLS.

The regression output is given in the table $8 \& 9$. 
Table 9. Elasticity of electricity consumption on Real GDP

\begin{tabular}{|c|c|c|c|c|}
\hline \multicolumn{5}{|c|}{ Dependent Variable: LGDP } \\
\hline \multicolumn{5}{|c|}{ Method: Dynamic Least Squares (DOLS) } \\
\hline \multicolumn{5}{|c|}{ Sample (adjusted): 19792012} \\
\hline \multicolumn{5}{|c|}{ Included observations: 34 after adjustments } \\
\hline \multicolumn{5}{|c|}{ Cointegrating equation deterministics: $\mathrm{C}$} \\
\hline \multicolumn{5}{|c|}{ Automatic leads and lags specification (lead $=0$ and lag $=7$ based on SIC criterion, $\max =7$ ) } \\
\hline \multicolumn{5}{|c|}{ HAC standard errors \& covariance (Bartlett kernel, Newey-West fixed bandwidth $=4.0000$ ) } \\
\hline Variable & Coefficient & Std. Error & t-Statistic & Prob. \\
\hline LEC & 0.860591 & 0.061592 & 13.97245 & 0.0000 \\
\hline $\mathrm{C}$ & 6.365744 & 0.824508 & 7.720654 & 0.0000 \\
\hline R-squared & 0.979338 & Mean depe & & 16.77797 \\
\hline Adjusted R-squared & 0.971590 & S.D. depen & & 0.580301 \\
\hline S.E. of regression & 0.097812 & Sum squar & & 0.229612 \\
\hline
\end{tabular}

From the above output in Table 9, it can be interpreted that about $97 \%$ of variation in growth in growth in real GDP is explained by variations in growth in electricity consumption. The LEC coefficient is statistically significant and an increase of $10 \%$ in electricity consumption is likely to increase the real GDP by $8.6 \%$. Since, India is poised to grow at a rate of $8 \%$ in real terms; the electricity consumption should grow by $10 \%$ annually. At $99 \%$ confidence level, the growth in electricity consumption is observed to be a statistically significant impact growth in GDP in India. Zero p-value corroborates this observation.

Table 10. Elasticity of real GDP on electricity consumption

\begin{tabular}{|c|c|c|c|c|}
\hline \multicolumn{5}{|c|}{ Dependent Variable: LEC } \\
\hline \multicolumn{5}{|c|}{ Method: Dynamic Least Squares (DOLS) } \\
\hline \multicolumn{5}{|c|}{ Sample (adjusted): 19722012} \\
\hline \multicolumn{5}{|c|}{ Included observations: 41 after adjustments } \\
\hline \multicolumn{5}{|c|}{ Cointegrating equation deterministics: $\mathrm{C}$} \\
\hline \multicolumn{5}{|c|}{ Automatic leads and lags specification (lead $=0$ and lag= 0 based on SIC criterion, $\max =4$ ) } \\
\hline \multicolumn{5}{|c|}{$\begin{array}{l}\text { HAC standard errors \& covariance (Prewhitening with lags }=1 \text { from SIC maxlags }=1 \text {, Bartlett } \\
\text { kernel, Newey-West fixed bandwidth }=4.0000 \text { ) }\end{array}$} \\
\hline Variable & Coefficient & Std. Error & t-Statistic & Prob. \\
\hline LGDP & 1.197778 & 0.173405 & 6.907404 & 0.0000 \\
\hline $\mathrm{C}$ & -7.785831 & 2.854242 & -2.727811 & 0.0096 \\
\hline R-squared & 0.965361 & Mean depe & var & 12.10851 \\
\hline Adjusted R-squared & 0.963538 & S.D. depen & & 0.796471 \\
\hline S.E. of regression & 0.152086 & Sum squar & & 0.878948 \\
\hline
\end{tabular}

In Table 10, 96\% of variation in growth in electricity consumption is explained by variations in growth in real GDP. The LGDP coefficient is statistically significant and an annual growth of real GDP by $8 \%$ will lead to annual increase of electricity consumtion by $9.5 \%$. At $99 \%$ confidence level, the LGDP is observed to be a statistically significant with zero p-value corroborates this observation.

The elasticity of 1.19 is in tune with the average elasticity from 1969-2012 (Fourth Plan to Eleventh Plan Period) is calculated at 1.27 calculated by the Planning Commission.

However, the estimate of elasticity of GDP w.r.t electricity consumption by the Ministry of Power at 0.90 for the period 2012-2017 is much lower than long run elasticity of 1.19 .

\section{Conclusions and Policy Implications}

It is to be noted that the previous studies tried to relate the aggregate energy consumption with economic growth in India but there may be a practical difficulty in aggregating the various forms of real energy consumption as their units of measurement differ. The conversion depends upon the quality or productivity of energy. Therefore, the present study makes a departure from the earlier studies by trying to relate only electricity as energy consumption with economic growth. This will help to have different policy strategies in devising the demand for electricity. The previous studies have either taken aggregate energy consumption or if there is a disaggregation, 
they have considered some forms of energy and leaving the most important component of energy i.e. electricity. Probably this is the reason why the studies have employed the traditional co-integration technique.

This paper has examined the existence and direction of causality between electricity consumption and economic growth in India using the annual data covering the period 1950-1951 to 1996-1997. The two step procedures of Engel Granger approach and VAR Granger Causality/Block Exogeneity Wald tests are applied to establish both long term and shot term causality. Empirical results have established the existence of long run as well as short run causality running from electricity consumption to economic growth without any feedback effect. Thus, a growth in electricity consumption is responsible for a higher economic growth. The findings of this empirical study is in consensus with the earlier findings (Table 1) excepting one (Ghosh, 2002) in the context of India. This result can be interpreted as follows.

The results of this study reject the neo classical theory of neutrality of energy consumption. Since, the causality runs from electricity consumption to GDP in India, electricity consumption is a limiting factor on GDP growth.

The policy of "energy must lead economic growth" should be emphasized for a long period which is contextually more important as a subdued growth rate of $4.5 \%$ and $4.9 \%$ has been witnessed during 2012-2013 and 2013-2014 respectively (Note 14).

The findings of this study are relevant to policymakers. Since, the Indian Economy is energy dependent, and as consequence, a conservation policy may counterproductive in slowing down the economy with adverse socio-economic effects.

The expansion of industrial and commercial sectors where electricity has been used as basic energy input because of its clean and efficient nature stimulates economic growth. The share of GDP by industrial sector and services sector are the highest and, they consume maximum electricity as compared to others category of consumers. Electricity consumption in agricultural and transport sector has also accelerated to keep pace with country's economic growth. The household sectors use the electricity at the cheapest form of energy. This helps in to add to their financial savings. Since, the household sectors are the major contributor of the total saving of the Indian economy; these savings are used to finance capital formation which leads to higher economic growth.

Since 1970-1971, the growth rate in electricity consumption in household sector, commercial sector, Agricultural sector and Railways is peaking up. It can be safely deduced that their involvement in economic activities has been growing up. The component wise of National Account Statistics corroborate this.

The result has important policy implications. India being, the fourth largest consumer in the world, energy deficit is persistent since 1980-1981. The energy efficiency of India is very low. Low efficiency and high T\&D loss are the limiting factors on the economic growth of India as energy consumption causes economic growth. Since, the economic growth needs more energy and the economic growth is contributed by construction, steel, metallurgy, equipment electro-analysis aluminum, glass and infra sectors which are which are high consumers of energy. This is concerned with the socio-economic development of the economy. The most important way to have efficiency gain is to reduce high T\&D loss in the electricity distribution sector.

Because of electricity consumption led growth is established, conservation of electricity will inhibits the economic growth. So, there is little scope for energy conservation policy. Besides, the long run elasticity of electricity consumption w.r.t real GDP is inelastic (0.86), more electricity consumption is required to induce higher growth in GDP. This is also corroborated by the mean buoyancy of GDP relative to electricity consumption which is estimated at 3.

Nevertheless, if the high T\&D loss in the distribution sector can be reduced to $15 \%$ level as envisaged in Accelerated Power Development Restructuring Program (APDRP, 2002), then energy conservation is possible along with efficiency gain without affecting the end consumers. Facilitation of cleaner and renewable forms of higher quality from hydro and thermal based electricity would help in efficiency gain.

The outlook for real GDP growth in India for the remaining year of 12th Plan period (2012-2017) is 8\%. With elasticity of 1.19 , the requirement of energy will grow at $9.52 \%$. The Energy requirement was $998.11 \mathrm{BU}$ in 2012-2013. At the end of 2016-2017, the energy requirement will be 1436 BU. This compares fairly well with the projection of energy requirement of 1403 BU at the end of 2016-2017 by Ministry of Power, Govt. of India. If the average T\&D losses in the remaining four years are pegged at $23 \%$, the projected net generation of electricity will be at $1766 \mathrm{BU}$ at the end of 12th Plan Period.

In order to ensure sustainable economic growth, a sufficient amount of energy supply must be ensures. The formulate and implement energy policy that will take care of energy security, prevent excessive energy consumption and improve energy efficiency, reducing the energy intensity and also to encourage to create new 
energy sources are the challenging task for policy makers.

From sustainability point of view in the long run, the growth and development in India, policy intervention is required to change its economic structure towards a more efficiency-oriented and less resource-depleting one and to rely more on renewable energy sources. Renewable energy technologies have an enormous potential to solve energy problems in India.

\section{References}

Adom, K. A. (2011). Electricity Consumption-Economic Growth Nexus:The Ghanaian Case. International Journal of Energy Economics, 1(1), 18-31.

Akarca, A. T., \& Long, T. V. (1980). On the Relationship between Energy and GNP: A Reexamination. Journal of Energy and Development, 5, 326-331.

Akinlo, A. E. (2008). Energy consumption and economic growth: evidence from 11 African countries. Energy Economics, 30, 2391-2400. http://dx.doi.org/10.1016/j.eneco.2008.01.008

Al-Iriani, M. A. (2006). Energy-GDP relationship revisited: an example from GCC countries using panel causality. Energy Policy, 34(17), 3342-3350. http://dx.doi.org/10.1016/j.enpol.2005.07.005

Anonymous. (2012). Energy Statistics. Ministry of Statistics and Program Implementation, GOI, New Delhi.

Anonymous. (2012). Report of The Working Group on Power for Twelfth Plan (2012-2017). Ministry of Power, GOI, New Delhi.

Anonymous. (2014). Annual Report (2013-2014) on the working of State Power Utilities \& Electricity Departments. Planning Commission, GOI, New Delhi.

Asafu-Adjaye, J. ( 2000). The relationship between energy consumption, energy prices and economic growth: time series evidence from Asian developing countries. Energy Economics, 22, 615-625. http://dx.doi.org/10.1016/S0140-9883(00)00050-5

Borozan, D. (2013). Exploring the relationship between energy consumption and GDP: Evidence from Croatia. Energy Policy, 59, 373-381. http://dx.doi.org/10.1016/j.enpol.2013.03.061

Campo, J., \& Sarmiento, V. (2013). The Relationship between Energy Consumption and GDP: Evidence from a Panel of 10 Latin American Countries. Latin American Journal of Economics, 50, $233-255$. http://dx.doi.org/10.7764/LAJE.50.2.233

Cheng, B. (1995). An investigation of cointegration and causality between energy consumption and economic growth. Journal of Energy Development, 21, 73-84.

Cheng, S. B., \& Lai, W. T. (1993). An investigation of co-integration and causality between energy consumption and economic activity in Taiwan, Province of China. Energy Economics, 19, 435-444. http://dx.doi.org/10.1016/S0140-9883(97)01023-2

Enders, W. (2003). Applied Econometric Time Series. Hoboken, NJ: Wiley.

Engle, R. F., \& Granger, C. W. J. (1987). Cointegration and Error Correction: Representation, Estimation and Testing. Econometrica, 55(2). http://dx.doi.org/10.2307/1913236

Erol, U., \& Yu, E. S. H. (1987). On the causal relationship between energy and income for industrialised countries. Journal of Energy and Development, 9, 75-89.

Fatai, K., Oxley, L., \& Scrimgeour, F. G. (2004). Modelling the causal relationship between energy consumption and GDP in New Zealand, Australia, India, Indonesia, the Philippines and Thailand. Mathematics and Computers in Simulation, 64, 431-445. http://dx.doi.org/10.1016/S0378-4754(03)00109-5

Ghosh, S. (2002). Electricity consumption and economic growth in India. Energy Policy, 30, 125-129. http://dx.doi.org/10.1016/S0301-4215(01)00078-7

Glasure, Y. U., \& Lee, A. R. (1997). The macroeconomic effects of relative prices, money, and federal spending on the relationship between U.S. Energy consumption and employment. The Journal of Energy and Development, 22(1), 81-91.

Govt. of India. (n.d.). Economic Survey (Various Issues). Ministry of Finance, Economic Division, New Delhi.

Gujarati, D. (1995). Basic Econometrics (pp. 725-729). New York: McGraw- Hill Inc.

Hondroyiannis, G., Lolos, S., \& Papapetrou, G. (2002). Energy consumption and economic growth: assessing the evidence from Greece. Energy Economics ,24, 319-336. http://dx.doi.org/10.1016/S0140-9883(02)00006-3 
Hou, Q. (2009), The Relationship between Energy Consumption Growths and Economic Growth in China: International Journal of Economics and Finance, 1(2), 232-237. http://dx.doi.org/10.5539/ijef.v1n2p232

Kraft, J., \& Kraft, A. (1978). On the relationship between energy and GNP. Journal of Energy Development, 3 , 401-403.

Kwiatkowski, D., Phillips, P. C. B., Schmidt, P., \& Shin, Y. (1992). Testing the null hypothesis of stationarity against the alternative of a unit root: How sure are we that economic time series have a unit root? Journal of Econometrics, Elsevier, 54(1-3), 159-178. http://dx.doi.org/10.1016/0304-4076(92)90104-Y

Lee, C. C. (2005). Energy consumption and GDP in developing countries: A cointegrated panel analysis. Energy Economics, 27, 415-427. http://dx.doi.org/10.1016/j.eneco.2005.03.003

Maddala, G. S. (2001). Introduction to Econometrics (3rd ed., pp. 547-570).

Masih, A. M. (1996). Energy consumption, real income and temporal causality: results from a multi-country study based on cointegration and error-correction modeling techniques. Energy Economics, 18(3), 165-183. http://dx.doi.org/10.1016/0140-9883(96)00009-6

Morimoto, R., \& Hope, C. (2004). The impact of electricity supply on economic growth in Sri Lanka. Energy Economics, 26, 77-85. http://dx.doi.org/10.1016/S0140-9883(03)00034-3

Oh, W., \& Lee, K. (2004). Causal relationship between energy consumption and GDP revisited: the case of Korea 1970-1999. Energy Economics, 26, 51-59. http://dx.doi.org/10.1016/S0140-9883(03)00030-6

Pokharel, S. H. (2006). An Econometrics Analysis of Energy Consumption in Nepal. Energy Policy, 1-12.

Soytas, U., \& Sari, R. (2003). Energy consumption and GDP: causality relationship in G-7 countries and emerging markets. Energy Economics, 25, 33-37. http://dx.doi.org/10.1016/S0140-9883(02)00009-9

Stern, D. I. (1993). Energy use and economic growth in the USA, a multivariate approach. Energy Economics, 15, 137-150. http://dx.doi.org/10.1016/0140-9883(93)90033-N

Stock, J. K., \& Watson, M. (1993). A simple estimator of cointegrating vectors in higher order integrated systems. Econometrica, 61, 783-820. http://dx.doi.org/10.2307/2951763

Wolde-Rufael, Y. (2004). Disaggregated energy consumption and GDP, the experience of Shangai, 1952-1999. Energy Economics, 26, 69-75. http://dx.doi.org/10.1016/S0140-9883(03)00032-X

World Energy Economic Outlook. (2013). International Energy Agency.

Yang, H. Y. (2000). A note on the causal relationship between energy and GDP in Taiwan. Energy Economics, 22, 309-317. http://dx.doi.org/10.1016/S0140-9883(99)00044-4

Yu, E. S. H., \& Choi, J. Y. (1985). The causal relationship between energy and GNP: An International comparison. Journal of Energy and Development, 10, 249-272.

Yu, E. S. H., \& Hwang, B. K. (1984). The Relationship between Energy and GNP: Further Results. Energy Economics, 6, 186-190. http://dx.doi.org/10.1016/0140-9883(84)90015-X

Yu, E. S. H., \& Jin, J. C. (1992). Cointegration Tests of Energy Consumption, Income, and Employment. Resources and Energy, 14, 259-266. http://dx.doi.org/10.1016/0165-0572(92)90010-E

\section{Notes}

Note 1. Ministry of Power, GOI.

Note 2. Ministry of Power: http://powermin.nic.in/indian_electricity_scenario/introduction.htm

Note 3. Ministry of Power, GOI (2013).

Note 4. US Energy Information Administration. http://www.eia.gov/countries/analysisbriefs/India/india.pdf

Note 5. Energy Statistics, 2012. MOSPI, GOI.

Note 6. Total generation is sum of net generation, energy received from captive plan and energy imported. The net generation is gross generation net of auxiliary consumtion.

Note 7. CAGR is calculated taking the OLS regression model: $\log (\mathrm{y})=\mathrm{c}+\mathrm{r}^{*} \mathrm{t}$, where $\mathrm{r}$ is the CAGR and $\mathrm{y}$ is the variable for which $r$ is calculated.

Note 8. http://www.wec-indicators.enerdata.eu/world-rate-of-electricity-T-D-losses.html 
Note 9. Energy Statistics, 2012 : MOSPI, GOI.

Note 10. International Energy Agency (IEA).

Note 11. Enerdata: World Energy Council.

Note 12. Economic Survey: Ministry of Finance, GOI.

Note 13. Bai -Perron (Econometric Journal,2003) multiple break points shows three break points both in electricity consumption and GDP during 1970-1971 to 2011-2012.

Note 14. MOSPI.

\section{Copyrights}

Copyright for this article is retained by the author(s), with first publication rights granted to the journal.

This is an open-access article distributed under the terms and conditions of the Creative Commons Attribution license (http://creativecommons.org/licenses/by/3.0/). 